\title{
LIBRARIANS AND POST TRUTH WORLD: PELUANG DAN STRATEGI PERPUSTAKAAN DI TENGAH CRISIS OF CRITICAL THINKING
}

\author{
Indah Rachma Cahyani \\ Pustakawan Universitas Airlanga \\ indah.rachma@staf.unair.ac.id
}

\begin{abstract}
ABSTRAK
Kemudahan akses informasi membuat masyarakat dengan mudah memproduksi informasi, post truth era membuat kita leluasa untuk memproduksi, menggunakan, menyimpan informasi, sekalipun informasi tersebut adalah sebuah kebohongan dan jauh dari kata benar, baik itu informasi yang bersifat daily life hingga informasi yang disajikan untuk akademisi. Artikel ilmiah ini menggunakan menggunakan metode analisis kajian pustaka, dengan mengumpulkan berbagai artikel ilmiah, penelitian yang berkaitan dengan tema kajian yang akan dibahas. Penulis memiliki tujuan untuk menggambarkan lebih jauh strategi pustakawan dalam tantangan menghadapi meluasnya kualitas informasi di era Post truth, selain itu penulis juga ingin menggambarkan tantangan serta peluang bagi pustakawan di era post truth. Artikel ilmiah ini mengungkapkan bahwa keberadaan perpustakaan dan pustakawan di post truth era masih dan lebih dibutuhkan. Pustakawan mampu menjadi "penjernih" di dalam "keruhnya" informasi, kesalahan dalam informasi akan mempengaruhi seseorang dalam pengambilan keputusan. Pustakawan dan perpustakaan akan terus digunakan sebagai jembatan informasi yang mampu memberikan alternatif-alternatif dalam pemilihan informasi yang tepat dan akurat.
\end{abstract}

Kata kunci: post truth, perpustakaan, pustakawan, tantangan, strategi

\section{PENDAHULUAN}

Saat ini komunikasi informasi ilmiah menghadapi tantangan baru, ilmu pengetahuan yang dahulu didefinisikan sebagai sarana yang tepat untuk menginformasikan kebijakan tidak lagi memiliki bobot seperti dulu, hal ini dikarenakan adanya kecenderungan sebuah informasi diexpose dan dikomentari pada mass media, beberapa kalangan akademisi menyebut kondisi ini sebagai zaman pasca-kebenaran atau post truth. Dimulai tahun 2016 kita ditunjukkan sebuah keadaan dimana fakta-fakta obyektif kurang berpengaruh dalam membentuk opini publik untuk menarik emosi atau kepercayaan pribadi seseorang, keadaan ini sesuai dengan terjadinya penolakan terhadap kemapanan tulisan para ahli, elit, pejabat, dan ilmuwan penelitian yang telah teruji dalam bentuk media pada arus utama. Hal tersebut tidak jarang menimbulkan tantangan dalam upaya mendorong massa terutama ketika mengomunikasikan fakta tentang perubahan oponi kepada publik. Diera pasca-kebenaran atau post truth kita melihat adanya kebohongan, propaganda dan berita palsu yang banyak mengangkat masalah makna dalam sebuah wacana. 
Peristiwa sejarah baru-baru ini telah menunjukkan kepada kita bahwa penghapusan semua substansi dari kebenaran dapat dicapai ketika perbedaan antara fakta dan fiksi tidak lagi bisa dibedakan. Serangkaian fenomena sosial berkontribusi besar terhadap hal ini, diantaranya yang paling menonjol adalah berita palsu dan akibatnya adanya produksi fakta atau kenyataan yang bersifat alternatif. Bagi banyak orang yang disebut sebagai fakta alternatif tidak lebih dari kebohongan dengan gaya terselubung, hal ini menyerupai banyak eufemisme lain yang telah menembus wacana budaya kontemporer dimana terdapat kebenaran paralel, kebenaran bernuansa pernyataan kontrafaktual hingga terjadinya misrepresentasi.

Indonesia sendiri tercatat dibulan Agustus 2018 terdapat 25 hoax yang diidentifikasi oleh Tim AIS Subdit Pengendalian Konten Ditjen Aplikasi Informatika. Di September 2018, naik menjadi 27 hoax, sementara di Oktober dan November 2018 masing-masing di angka 53 dan 63 hoax kemudian pada desember 2018 jumlah hoax terus naik di angka 75 konten dan peningkatan jumlah konten hoax sangat signifikan terjadi pada bulan Januari dan Februari 2019. Sebanyak 175 konten hoax yang berhasil diverifikasi oleh Tim AIS Kemkominfo dimana angka ini naik dua kali lipat di Februari 2019 menjadi 353 konten hoax. Angka tersebut terus naik menjadi 453 hoax selama Maret 2019. Total 1.731 hoax sejak Agustus 2018 hingga April 2019 yang diidentifikasi, diverifikasi dan divalidasi oleh Tim AIS Kemekominfo, hoax kategori politik mendominasi diangka 620 item hoax. Kemudian disusul 210 hoax kategori pemerintahan, 200 hoax kategori kesehatan, 159 hoax terkait fitnah, 113 hoax terkait kejahatan dan sisanya hoax terkait isu agama, bencana alam, mitos, internasional dan isu lainnya (KemenKominfo, 2019).

Tinjauan buku "Etika Media di era Post Truth" yang ditulis oleh Kharisma Dhimas Syuhada (2017), menyebutkan ada perbedaan antara fake news dan hoax. Fake news adalah berita bohong, berita buatan atau berita palsu yang tidak berdasarkan kenyataan, hoax justru informasi palsu, berita yang bisa berisi fakta namun telah dipelintir atau direkayasa. Kata-kata hoax saat ini semakin sering digunakan dan disematkan ketika menyikapi berita yang sama sekali tidak ada faktanya. Pada zaman ini, hoax melekat pada seperangkat atribut fitnah yang digunakan untuk menjatuhkan pribadi seseorang, pada kenyataannya asal mula kata hoax diciptakan dalam bahasa Inggris dengan pengertian yang tidak serumit dan tidak sejahat demikian.

Saat ini seseorang bahkan dapat berbicara tentang satu sistem moral alternatif yang memungkinkan seseorang untuk berbohong tanpa dipengaruhi oleh rasa bersalah atau penyesalan, dan pertikaian tidak lagi dianggap sebagai kesalahan atau tidak jujur (Keyes, 2004). Berdasarkan pernyataan tersebut hal ini merupakan hasil dari "relativisasi" kebenaran dalam masyarakat kita. Relativisasi ini telah disetujui oleh prinsip-prinsip dekonstruksionisme poststrukturalis, lebih jauh hal ini telah didukung oleh saluran-saluran baru komunikasi virtual yang mudah diakses, siapapun dapat membangun filter sehingga kepercayaan terhadap kebenaran menjadi hampir mustahil sehingga dalam keadaan seperti ini, masyarakat cenderung mengabaikan apa yang orang lain katakan dan berpegang teguh pada keyakinan mereka sendiri.

Munculnya media sosial berarti bahwa informasi dapat menyebar luas dan dapat menyebar dengan cepat dengan tombol klik, tanpa memperhatikan sumber informasi tersebut. 
Kemampuan bagi mahasiswa dan peneliti untuk membedakan informasi yang dapat diandalkan dari berita yang menyesatkan atau palsu saat ini sangat penting, tidak hanya untuk mendapatkan pemahaman yang lebih baik tentang informasi yang disajikan kepada mereka, tetapi juga dalam memperoleh sumber dan kutipan yang akurat untuk kehidupan mereka dimasa mendatang. Berita palsu atau fake news adalah istilah yang sering digunakan, terutama di media sosial meskipun hal ini bukan konsep modern, namun kebangkitan teknologi telah membuatnya menjadi lebih mudah dari sebelumnya untuk menjadikan sumber-sumber yang sebelumnya tidak dapat diandalkan sebagai fakta. Sebagai ahli terlatih dalam mengevaluasi informasi, berita atau hasil penelitian, dan pustakawan perguruan tinggi harus siap untuk memimpin jalan dalam pertempuran melawan fake news dan hoax.

Artikel ini akan lebih jauh membahas mengenai peran dan tantangan pustakawan sebagai information manager dengan mengajar orang untuk berpikir kritis tentang informasi. Secara khusus artikel memberikan gambaran tantangan yang dihadapi pustakawan dan alasan pustakawan dan perpustakaan masih tetap dibutuhkan di era ini dengan pendekatan dari teori sosial kritis, pendekatan tersebut mampu menggambarkan secara komprehensif permasalahan di era post truth, mulai dari pemustaka sebagai information manager hingga user education.

\section{TINJAUAN PUSTAKA}

Kondisi Post truth telah meningkatkan platform media sosial yang sekarang berfungsi sebagai media komunikasi yang dominan, perkembangan yang telah terjadi berimplikasi pada perubahan dalam cara individu mengakses dan berinteraksi dengan informasi. Kendati demikian, hal ini bukan kali pertama nilai kebenaran dipertanyakan, tiga puluh lima tahun yang lalu ahli teori sosial kritis Jean Baudrillard mengatakan bahwa kita hidup di dunia dimana ada semakin banyak informasi, dan semakin sedikit makna (Baudrillard, 1994) dan berspekulasi bahwa informasi secara langsung merusak makna. Baudrillard juga mengatakan bahwa proliferasi informasi dalam masyarakat kontemporer telah memberikan lebih banyak peluang untuk perbedaan pendapat serta lebih banyak peluang untuk informasi yang salah yang berakibat sulitnya informasi menemukan validasi terhadap sumber yang didapatkan. Jürgen Habermas (1989) mengkritisi tentang transformasi struktural ruang publik borjuis, ia memiliki beberapa gagasan utama yang tetap berkaitan dengan teori dan kritik pasca kebenaran/post truth dan penjelasannya tentang alasan serta pertimbangannya mengenai publik yang secara bertahap dijajah oleh media berita dan tidak jarang ditawarkan untuk pembentukan opini publik yang dapat mengurangi fakta dari informasi yang sebenarnya, dalam hal ini setiap orang dapat menemukan kebenaran mengenai diri mereka atau orang lain dari sebuah portal Web, hal ini juga menjadi penyebab kaum urban "menjelajah" secara luas melalui jejaring sosial dan muncul kembali berkali-kali setelah tidak aktif didunia virtual. Penyedia konten sering mengandalkan tajuk sensasional untuk menarik pembaca sehingga gagasan mengenai kebenaran telah kehilangan esensinya pada masyarakat kontemporer, misalnya untuk pengambilan keputusan mereka mengandalkan reputasi pada pengalaman sebelumnya bukan dari informasi yang valid. 
Berbicara tentang kondisi pasca kebenaran, menggemakan gagasan tentang pengetahuan Lyotard yang berpengaruh yakni The Postmodern Condition (1979) dan mengingatkan kembali kepanikan publik, namun fokus Lyotard lebih pada pergeseran mengenai narasi menyeluruh yang membenarkan klaim pengetahuan yaitu pengetahuan yang disahkan oleh "narasi besar" sisa masa pencerahan tentang kemajuan, sains, Marxisme, dan sebagainya. Lyotard menekankan jatuhnya metanaratif ini terkait dengan periode modern, dan menjamurnya penjelasan dan pembenaran yang kurang ambisius dan tidak total untuk pengetahuan, namun sebaliknya kondisi pasca kebenaran/post truth tidak hanya tentang fragmentasi membenarkan cerita untuk klaim kebenaran, tetapi ketika salah satu dilanda kecurigaan pada kebenaran sudah dianggap tidak jujur. Pasca kebenaran/post truth dikaitkan dengan beberapa jenis komunikasi utama, pernyataan atau narasi, yang semuanya merupakan subkelas komunikasi yang menipu dan biasa kita sebut sebagai informasi yang keliru, berita palsu, bom rumor, dan kebohongan. Disinformasi, bom rumor, dan berita palsu memiliki anteseden era komunikasi massa yang baik dalam keamanan sebuah informasi dan komunikasi komersial (iklan dan hubungan masyarakat) dan semua dapat dikatakan sebagai bentuk komunikasi strategis. Dalam sebuah tulisan yang berjudul Review of On Bullshit yang ditulis oleh Harry G. Frankfurt (2005) post truth tidak hanya tentang kebohongan dan keyakinan salah tetapi juga tentang kebingungan ditengah-tengah kerumitan informasi dan pembanding informasi yang berpengaruh yang membuat kesulitan dalam membedakan satu dari yang lain.

\section{METODE PENELITIAN}

Pada kajian ini penulis menggunakan metode Studi Literatur, dimana metode ini penulis membaca dan memahami berbagai macam buku-buku dan jurnal-jurnal ilmiah baik itu buku yang bersumber dari Buku digital dan jurnal ilmiah yang berasal dari sumber online, thesis, skripsi yang berkaitan dengan tantangan dan peluang perpustakaan di era post truth world. Dalam studi literatur ini sangat berguna dan bermanfaat bagi penulis karena penulis mampu mengetahui konsep-konsep secara detail dan mampu membuat kerangka berfikir khususnya dalam hal mengatur dan memilih mana referensi yang relevan dengan kajian yang dibuat (Koentjaraningrat, 1983).

\section{PEMBAHASAN}

\section{Kemunculan Criris of Critical Thinking}

Sebagaimana dinyatakan oleh Detmering dan Johson, (2011) berpikir kritis tentang informasi adalah komponen penting dalam penelitian, apakah seseorang menentukan database atau mesin pencari mana yang akan digunakan, artikel mana yang akan ditambahkan ke daftar pustaka, atau argumen mana yang harus dipercayai. Masalah dari menemukan metode yang efektif untuk mengembangkan keterampilan berpikir kritis merupakan tantangan signifikan bagi lembaga pendidikan nasional. Profesional di bidang ini telah membahas pentingnya mengembangkan keterampilan berpikir kritis selama lebih dari 
50 tahun. Diskusi dimulai dengan mendefinisikan pemikiran kritis. Studi Delphi, yang diselenggarakan oleh Facione pada akhir 1980-an, menetapkan definisi pemikiran kritis yang akan digunakan dalam menetapkan standar untuk kurikulum K-12, "kami memahami pemikiran kritis sebagai tujuan, penilaian peraturan sendiri, yang menghasilkan interpretasi, analisis, evaluasi , dan inferensi, serta penjelasan tentang pertimbangan bukti, konseptual, metodologis, crit-riologis, atau kontekstual yang menjadi dasar penilaian itu (Rickets dan Rudd, 2005)

Berdasarkan statement diatas bahwa latihan diperlukan untuk mengembangkan keterampilan berpikir kritis, Rickets dan Rudd percaya bahwa untuk memperkuat keterampilan berpikir kritis harus menggunakan pengalaman akademis yang menantang siswa untuk menganalisis ide-ide dan mengeksplorasi pemikiran mereka sendiri sehingga mendorong mereka untuk berpikir kritis dengan metode yang biasanya dianggap paling efektif dalam memberikan kesempatan untuk mengembangkan keterampilan berpikir kritis termasuk kegiatan seperti diskusi kelompok atau kelas, debat, dan studi kasus, yang sering menggunakan masalah kontroversial untuk menginspirasi keinginan dan pemikiran analitik pada siswa.

\section{Perpustakaan Sebagai Garda Terdepan Melawan Negative Effect dari Post Truth World}

Kehadiran New Media dalam hal ini membuat segalanya menjadi mudah, inovatif, efesien dan efektif dalam melakukan banyak hal, tak jarang kaum kapitalis pun memanfaatkan keadaan ini untuk mendapatkan keuntungan. New media sendiri adalah media digital yang memungkinkan adanya gambar, suara, audio visual, teks kemudian disimpan dalam format digital dan disebarluaskan melalui berbagai macam jenis kabel optik dan sistem transmini gelombang mikro (Flew, 2008). Dalam hal ini jaringan adalah komponen utama dalam membentuk masyarakat informasi yang didalamnya menggunakan New Media dalam pergerakannnya. Jaringan dalam New Media dapat diartikan sebagai infrastruktur yang menghubungkan komputer satu sama lain dan untuk berbagai perangkat eksternal, dan dengan demikian memungkinkan pengguna untuk berkomunikasi dan bertukar informasi (Shay, 1999).

Pustakawan sebagai pengelola informasi bisa dikatakan lebih penting daripada era sebelumnya, pustakawan dituntut untuk memahami penyebaran epidemi informasi yang tidak akurat dan membantu orang lain mendeteksi berita palsu, berita bohong dan hoax. Seorang pustakawan dituntut untuk memiliki keterampilan berpikir kritis mengenai media sehingga memiliki keterampilan evaluasi dan menjadi informasi lebih cerdas. Pustakawan memiliki peluang baru untuk menanamkan keterampilan ini kepada pemustaka. Pustakawan dilatih untuk membantu pemustaka berpikir kritis dan menentukan apakah yang mereka lihat dan baca dapat dipercaya. Pustakawan bertanggung jawab atas literasi digital dimana program ini bekerja untuk mengembangkan kepercayaan untuk menavigasi internet dan akses informasi online. Pustakawan diharapkan memberikan edukasi pada pemustaka untuk memastikan bahwa apa yang dikatakan sebuah sumber adalah benar. Salah satu masalah mendasar kita adalah mengasumsikan bahwa kata yang diterbitkan telah diubah. Media sosial seringkali bukanlah sumber yang dapat dipercaya, kita perlu belajar dimana mereka mendapatkan informasi. 
Sebagai bagian dari peran pustakawan dalam mendukung era post truth, pustakawan dituntut untuk memperjuangkan literasi informasi, Bundy (2002) mencatat pentingnya mengambil pendekatan yang melibatkan banyak individu untuk literasi informasi, tetapi literasi informasi ini sering digunakan hanya sebagai cara untuk memastikan bahwa mahasiswa dapat menemukan informasi yang tepat untuk mengerjakan tugas perkuliahan, bukan sebagai langkah utama dalam memproduksi informasi. Lebih jauh Mackey and Jacobson (2011) mengungkapkan bahwa konsep literasi informasi untuk praktisi/pustakawan telah berevolusi menjadi pengakuan akan pentingnya sumber online dan media sosial sebagai media bagi pengguna informasi untuk menjadi creator informasi. Mereka menunjukkan bahwa dimasa kontemporer, pemikiran ulang tentang literasi informasi diperlukan dengan menggeser fokus ke arah digital, dimana ini adalah sebuah metode baru yang mengarahkan pada bentuk baru konsep literasi.

Dahulu seorang mahasiswa yang menulis laporan/makalah penelitian tentang topik tertentu perlu memutuskan apakah artikel dari jurnal ilmiah seperti Nature adalah sumber yang lebih tepat daripada artikel dari majalah populer seperti Time, namun pada mahasiswa hari ini harus tahu bagaimana membedakan antara artikel yang diterbitkan oleh jurnal ilmiah asli dan artikel yang dibuat oleh jurnal predator dan palsu yang mirip yang mengklaim sebagai jurnal ilmiah dengan rating teratas. Keadaan hari ini semakin diperumit relativisme dari filsafat postmodern yang mendasari banyak pemikiran ilmiah postmodern. Postmodernisme menolak gagasan bahwa konsep-konsep seperti kebenaran ada sebagai absolut yang dapat diungkapkan melalui karya "otoritas".

Permasalahan lain adalah pertanyaan serius seputar legitimasi komunikasi ilmiah pada arus utama. Selain jurnal predator dan palsu, skandal baru-baru termasuk para peneliti memalsukan hasil, tinjauan pustaka yang curang untuk hambatan dalam menerbitkan studi sejenis memverifikasi atau membantah studi sebelumnya. Lanskap informasi yang dinamis dan sering kali tidak dapat diprediksi serta lingkungan pendidikan tinggi yang berubah dengan cepat dimana mahasiswa sering menjadi pencipta pengetahuan baru, bukan hanya konsumen informasi, Asosiasi Perguruan Tinggi dan Perpustakaan Penelitian (ACRL) meluncurkan Kerangka Kerja untuk Literasi Informasi bagi Pendidikan Tinggi, revisi pertama standar ACRL untuk literasi informasi dalam lebih dari 15 tahun (ACRL, 2015). Kerangka kerja mengakui bahwa literasi informasi terlalu sempit untuk dipahami sebagai "pencarian" sumber daya informasi yang dibagi ke dalam kategori "baik" dan "buruk".

Pendekatan baru ini meminta mahasiswa untuk meluangkan waktu sebagai upaya yang diperlukan untuk menentukan kredibilitas dan kesesuaian masing-masing sumber informasi untuk penggunaan yang mereka maksudkan. Sementara itu kita menyetujui Literasi Informasi untuk Pendidikan Tinggi, namun kita tidak melihatnya sebagai solusi utama untuk tantangan literasi informasi. Kemajuan nyata dalam literasi informasi akan membutuhkan kerjasama pustakawan, pengajar, dan manajemen pendidikan, tanpa upaya bersama kredibilitas informasi akan selalu dipertanyakan dan tenggelam kebisingan media.

Peluang: We Need Librarian and Library More Than Ever Before.

Post-kebenaran/post truth didefinisikan menunjukkan keadaan dimana fakta-fakta obyektif kurang berpengaruh dalam membentuk opini publik daripada menarik keyakinan 
dan emosi pribadi. Mengatasi perspektif dan wawasan baru dalam kritik di era pasca-kebenaran, pertanyaan-pertanyaan berikut harus dijawab: Bagaimana kita mendapatkan kebenaran dalam teks serta bagaimana kita mendapatkan makna dalam sebuah bacaan era pasca-kebenaran, dan akhirnya bagaimana perspektif baru kritik bacaan dapat diterapkan untuk mengkritik suatu teks. Perpustakaan telah lama dianggap sebagai bagian dari era post truth pada masyarakat dan lembaga-lembaga penting dalam mendukung demokrasi. Perpustakaan dan pustakawan dianggap mampu memunculkan kepercayaan untuk menyediakan sumber daya yang mendukung untuk melakukan pertukaran informasi di masyarakat yang aman (Rettig, 2009).

Dalam proses mendigitalkan sumber koleksi terdapat pengaruh yang dimiliki perpustakaan, proyek digitalisasi perpustakaan juga memberikan informasi kepada orang-orang yang tidak memiliki sumber daya untuk menjangkau ke perpustakaan. Pustakawan menggunakan teknologi internet yang sedang berkembang untuk melanjutkan misi dalam menyediakan akses informasi yang lebih baik. Internet adalah platform yang memungkinkan kemajuan, dan pustakawan adalah pemimpin dalam meningkatkan akses online ke informasi ilmiah. Gerakan akses terbuka membuat artikel-artikel ilmiah tersedia untuk semua pembaca online, dan pustakawan akan menjadi pendukung kuat gerakan ini, inisiatif penerbitan yang dipimpin pustakawan memanfaatkan sepenuhnya web dan umumnya dengan akses terbuka. Salah satu contoh penerbitan perpustakaan yang umum di perpustakaan akademik, adalah Institutional Repository. Repository ini mengumpulkan dan melestarikan jangkauan luas dari output pengetahuan yang diciptakan perguruan tinggi atau universitas, seperti kumpulan data yang dikumpulkan dalam studi penelitian.

Pustakawan dapat membantu kita menyortir berita asli dari yang palsu, dimana sebagian besar konten yang bermanfaat, akurat, dan menarik tersedia online, namun terkadang web diisi dengan informasi yang tidak akurat dan menyesatkan. Kepustakawanan selalu berbicara tentang memberikan informasi yang objektif, akurat, dan menarik yang memenuhi kebutuhan pemustaka, dan itulah sebabnya pustakawan ahli dalam literasi informasi. Google adalah mesin pencari yang handal dengan hasil pencarian yang begitu banyak, dan disaat yang sama banyak individu tidak tahu untuk menyaringnya berdasarkan tipe konten (seperti .pdf) atau sumber situs web (seperti .gov). Google menawarkan banyak tips pencarian, yang berguna namun secara umum, dan disinilah pustakawan dapat mengklarifikasi apa yang kita cari dan mencari cara terbaik untuk menggunakan Google atau banyak sumber daya lainnya untuk menemukan sesuai dengan kebutuhan informasi kita.

Tran dan Yerbury (2015) dalam sebuah penelitian yang dilakukan pada tahun 2014 menemukan bahwa mahasiswa cenderung menggunakan teknik yang mereka pelajari dalam program literasi informasi untuk mengatasi filter buble yang dibuat oleh Google, tampaknya praktik ini mengalami perubahan dan lebih menerima hasil pencarian mereka dari pencarian Google. Filter buble yang menjadi perhatian terbesar para pustakawan ini bukanlah yang diciptakan melalui penggunaan Google atau media sosial, ini adalah standar yang dibuat oleh dosen atau pengajar dalam menentukan bacaan untuk pembelajaran di universitas. Fenomena diatas menunjukan bahwa mahasiswa tidak memiliki kesempatan untuk menantang diri mereka untuk menerapkan prinsip-prinsip pengidentifikasian informasi yang relevan 
berkualitas tinggi karena tidak diberi kesempatan untuk menjelajahi "toko-toko" pengetahuan yang mereka butuhkan dalam bidang mereka dan lebih jauh untuk pengambilan keputusan.

Penekanan pada pemikiran kritis disajikan oleh seseorang sebagai bentuk memberikan metode untuk mengidentifikasi informasi berkualitas tinggi yang ditemukan melalui sumber lain dan karena itu sebagai kelanjutan dari rezim kebenaran, namun penekanan pada pemikiran kritis juga dapat menjadi bukti munculnya individualisme, dengan fokus pada tanggung jawaban individu. Sampai taraf tertentu fokus pada individu ini dapat dilihat ada dalam hubungan instrumental antara program literasi informasi, pemikiran kritis, tugas penilaian dan nilai. Disisi lain seperti yang ditunjukkan oleh Rivano Eckerdal (2017), bahwa hal ini bukan bukti pergeseran kearah individualisme dari rezim pasca kebenaran, tetapi bukti dari pandangan demokrasi umumnya disebut sebagai demokrasi liberal, dimana penekanannya adalah pada tanggung jawab individu untuk membuat keputusan yang baik.

\section{PENUTUP}

Kita hidup diera pasca-kebenaran/post truth dimana berita palsu, setengah kebenaran, dan fakta tersebar luas. Saat ini siapa pun dapat membuat halaman web, artikel berita, atau posting di sebuah blog pribadi yang memposisikan pikiran atau keyakinan mereka sebagai kebenaran. Sebagai seorang profesional informasi yang baru muncul, pustakawan telah memikirkan tentang jenis-jenis keterampilan yang dimiliki agar dapat ditawarkan kepada pemustaka untuk membantu mereka menavigasi informasi di era pasca kebenaran/post truth. Beberapa dari pustakawan mengembangkan literasi informasi dan menyediakan akses pada sumber yang memiliki reputasi, mendorong pemikiran kritis, dengan memperhatikan informasi yang dibagikan tersebut menjadi kekuatan untuk perubahan positif di masyarakat.

Alternatif lainnya adalah pustakawan dapat membantu meningkatkan literasi informasi komunitas mereka adalah dengan menyediakan akses ke penelitian dan repositori yang memiliki reputasi baik. Berpikir kritis tentang informasi dan sumber informasi adalah keterampilan lain yang dapat diajarkan kepada pemustaka sehingga mereka (pemustaka) tahu cara berpikir kritis tentang dimana dan bagaimana mereka mengakses informasi. Pustakawan dan perpustakaan masih terus dan lebih dibutuhkan di era ini, pustakawan khususnya ditempatkan untuk menjadi agen perubahan positif dengan melengkapi keterampilan masyarakat dalam mengakses informasi secara benar, bukan saatnya bagi para profesional informasi untuk bersikap netral tentang berita palsu, hoax, fake news, dan ini saatnya untuk proaktif, kritis, menangani masalah ini dengan kemampuan literasi informasi, media yang baik. 


\section{DAFTAR PUSTAKA}

American Library Association. 2015. Framework for Information Literacy for Higher Education, February 9, 2015. http://www.ala.org/acrl/standards/ilframework. (diakses April 14, 2020)

Barton, D., Hamilton, M., \& Ivanic, R. 2000. (Eds.) Situated literacies: reading and writing in context.

Baudrillard, Jean. 1988. Selected Writings, ed. Mark Poster. Stanford; Stanford University Press.

Detmering, R., \& Johnson, A. M. 2011. Focusing on the Thinking, Not the Tools: Incorporating Critical Thinking into an Information Literacy Module for an Introduction to Business Course. Journal of Business \& Finance Librarianship, 16(2), 101-107. doi:10.1080/08963568.2011.554771

Flew, Terry. 2008. New Media: An Introductio (3 ${ }^{\text {rd }}$ edition). South Melbourn: Oxford University Press.

Habermas, J. 1989. The Structural Transformation of the Public Sphere: An Inquiry into a Category of Bourgeois Society (Trans. by Burger T. with the Assistance of Lawrence F.). Cambridge: Polity Press.

Kementerian Komunikasi dan Informasi RI (Komenkominfo RI). 2019. Temuan Kominfo: Hoax Paling Banyak Beredar di April 2019, Jakarta: KemenKominfo RI.

Keyes, Ralph. 2004. The Post truth era: Dishonesty and Deception in Contemporary Life. New York: St. Marti's Press.

Koentjaraningrat. 1983. Metode-Metode Penelitian Masyarakat. Gramedia. Jakarta London: Routledge.

Lyotard, Jean-Fran, Bennington, Geoff, Foreword, Brian Massumi., Jameson, Fredric.1979. The Postlllodern Condition: A Report on Kno-wledge. USA: Manchester University Press.

Pfeifer, Karl. 2006. Review of On Bullshit by Harry G. Frankfurt. Dialogue: Canadian Philosophical Review. 45. 617-620.

Ricketts, John \& Rudd, Rick. 2005. Critical Thinking Skills of Selected Youth Leaders: The Efficacy of Critical Thinking Dispositions, Leadership, and Academic Performance. Journal of Agricultural Education. 32. 10.5032/jae.2005.01032.

Shay. W 1999. Understanding data communications and network. Pasific Grove, CA: Brooks Cole.

Simon, H. A. 1998. "Problem Solving and Education." Problem Solving and Education: Issues in Teaching and Research. 81-96. Eds. David T. Tuma and Frederik Reif. Hillsdale, NJ: Lawrence Erlbaum.

Syuhada, Kharisma Dhimas. 2017. Etika Media di Era Post Truth. Jurnal Komunikasi Indonesia, 5(1).1-5. 